\begin{tabular}{|c|c|c|}
\hline  & $\begin{array}{l}\text { ESCOLA DE } \\
\text { HUMANIDADES }\end{array}$ & $\begin{array}{l}\text { Revista Digital do Programa de Pós-Graduação em Letras da PUCRS } \\
\text { Letrônica, Porto Alegre, v. 13, n. 1, p. 1-15, jan.-mar. } 2020 \\
\text { e-ISSN: 1984-4301 }\end{array}$ \\
\hline ddit $h$ & $\mathrm{org} / 10.15448 / 1984-4301.2020 .1 .351$ & \\
\hline
\end{tabular}

\title{
Literatura colombiana afrodescendente: voz afrofeminina no poema “Negra soy" de Mary Grueso Romero
}

\author{
Afrodescendent Colombian Literature: Afrofeminina voice \\ in the Poem "Negra Soy" of Mary Grueso Romero \\ Literatura Colombiana afrodescendiente: voz afrofemenina \\ en el poema "Negra Soy" de Mary Grueso Romero
}

\section{Benedito Ubiratan de Sousa Pinheiro Júnior ${ }^{1}$ orcid.org/0000-0003-1493-7171 birajr_78@yahoo.com.br}

\section{Adrielle Sena Branco ${ }^{2}$ orcid.org/0000-0002-3042-5160 annamonikysena@gmail.com}

\section{Iris Andrade Torres ${ }^{2}$} orcid.org/0000-0002-7242-5097 irisandradetorres@gmail.com

Recebido em: 19 ago. 2019 Aprovado em: 29 out. 2019 Publicado em: 7 abr. 2020.

\section{(c) (1)}

Artigo está licenciado sob forma de uma licença Creative Commons Atribuição 4.0 Internacional.
Resumo: O espaço da mulher na literatura afrocolombiana sempre foi secundário, uma vez que entre os primeiros autores que figuram esse tipo de escritura não aparecem nomes femininos. Todavia, a escrita afrofeminina ganhou espaço a partir da primeira antologia de escritoras afrocolombianas intitulada iNegras Somos!: Antología de 21 Mujeres Poetas Afrocolombianas de la Región Pacífica (2008), construída por Guiomar Escobar e Alfredo Zamorano, dando visibilidade a diversas poetas afrodescendentes. Por isso, esta investigação tem por objetivo apresentar como a voz afrofeminina é representada na literatura afrocolombiana, por meio do poema "Negra soy", de Mary Grueso Romero, evidenciando a autoria feminina e o protagonismo da mulher na literatura. O estudo permitiu observar que os escritos feitos por essas mantêm viva a história e a identidade étnico-racial deste grupo por intermédio da produção poética. A pesquisa será realizada por meio de uma revisão bibliográfica. Para tanto, foram utilizados os autores Espitia (2012), Palmeira (2012) e Zamorano e Escobar (2008).

Palavras-chave: Literatura afrocolombiana. Afrodescendente. Voz afrofeminina. Mary Grueso Romero.

Abstract: Women's space in Afrocolombian literature has always been secondary, since in the first authors that figure this type of writing there are no female names. However, Afrofemale writing gained space from the first anthology of Afrocolombian writers entitled iNegras Somos!: Antologia de 21 Mujeres Poetas Afrocolombianas de la Región Pacifica (2008), built by Guiomar Escobar e Alfredo Zamorano, giving visibility to several afrodescendent poets. Therefore, this research aims to present how the Afrofeminine voice is represented in Afrocolombian literature, through Mary Grueso Romero's poem Negra soy, highlighting female authorship and female protagonism in the literature. The study showed that their writings keep alive the history and ethnic-racial identity of this group through poetic production. The research will be conducted through a literature review. For this, the authors Espitia (2012), Palmeira (2012) and Zamorano were used; Escobar (2008).

Keywords: Afrocolombian literature. Afrodescendent. Afrofeminina voice. Mary Grueso Romero.

Resumen: El espacio de la mujer en la literatura afrocolombiana siempre ha sido secundario, ya que entre los primeros autores que presentam este tipo de escritura no aparecen nombres femeninos. Sin embargo, la escritura afrofemenina ganó terreno con la primera antología de escritores afrocolombianos titulada iNegras Somos!: Antología de 21 mujeres poetas afrocolombianas de la región del Pacífico (2008), construida por Guiomar Escobar y Alfredo Zamorano, dando visibilidad a varios poetas afrodescendientes. Por lo tanto, esta investigación tiene como objetivo presentar cómo se representa la voz afrofemenina en la literatura afrocolombiana, a través del poema de Mary Grueso Romero "Negra soy", destacando la autoria femenina y el protagonismo femenino en la literatura. El estudio mostró que sus escritos mantienen viva la historia y la identidad étnico-racial 
de este grupo a través de la producción poética. La investigación se realizará a través de una revisión de la literatura. Para ello, se utilizaron los autores Espitia (2012), Palmeira (2012) y Zamorano; Escobar (2008).

Palabras clave: Literatura afrocolombiana. Afrodescendiente. Voz afrofeminina. Mary Grueso Romero.

\section{Considerações iniciais}

A construção poética lírica traz em seus enredos, de modo geral, uma exposição de sentimentos da humanidade, a essência de sua alma, de suas dores e de seu contato com a natureza, isso por meio de frases que emocionam e tocam a sensibilidade, trata-se da representação de algo que sugere emoção utilizando os recursos disponiveis pela linguagem, em um constante movimento de criá-la e recriá-la. O poema definese como um ser de linguagem, ou seja, o poeta produz a linguagem, produzindo poemas, onde cria e recria a linguagem de forma constante. considerando a linguagem um ser vivo no qual o seu mundo ganha troncos, ramos, flores e frutos. Um bom poema não se acaba, possibilita a criação de modelos de sensibilidade, assim o poema como um ser concreto de linguagem, torna-se abstrato quando, por exemplo, se tenta explicar sobre uma pessoa ou uma situação da vida, por melhor que seja a explicação nunca ambas podem ser substituidas (PIGNATARI, 2005, p. 11-12).

Os poemas da autora Mary Grueso Romero não são diferentes, a poeta caucana concretiza por meio de suas obras a defesa da etnia negra, especificamente do povo afrocolombiano, onde estes "[...] criaram novas formas de cultura a partir de muitas fontes diferentes, usando elementos particulares e principios culturais de fontes diversas, a fim de criar para eles mesmos e para outras pessoas algo que seja identificável como cultura "negra" ou "afro-colombiana", ou como configurações regionais particulares da cultura (por exemplo, da região da costa do Pacífico) associadas à negritude" (WADE, 2003, p. 152). Conforme evidencia María Mercedes Jaramillo sobre os escritos de Mary Grueso: "A autora canta sua terra, seu povo e reivindica a linguagem coloquial do Litoral Pacífico, enquanto enriquece o verso com o ritmo e a musicalidade das palavras de sabor africano3" (JARAMILLO, 2007. p. 218, tradução nossa).

Mary Grueso Romero é uma autora de uma reconhecida voz poética, que retrata com orgulho em suas obras as características das tradições de seu povo e defende a sua herança cultural, uma vez que a escritora é descendente de escravos, por isso faz de suas obras um reforço da identidade afrodescendente ${ }^{4}$, por meio do resgate da negritude e a valorização de seus ancestrais, assim como retrata o momento de escravidão e os abusos cometidos contra os escravizados ao longo da história. A autora caucana utiliza a sua marcante voz em suas apresentações dinamizando fortemente as suas palavras em seus textos, que abarcam também as paisagens do Pacífico Colombiano e, principalmente, demonstram a consciência de uma mulher negra que valoriza a sua condição de afrodescendente e que com orgulho defende a sua herança cultural.

As obras escritas pela autora Mary Grueso, compõem os mais diferentes temas porém, alguns podem ser considerados a essência de outros, há um resgate da memória da negritude de seus ancestrais e um trabalho com a consciência de ser uma mulher negra descendente de escravos, porém não faz somente nesta obra que estamos trazendo para análise e sim em todas as suas manifestações, sejam elas orais ou escritas. Por isto, o presente texto tem por objetivo apresentar os elementos que destacam a presença da voz afrofeminina, uma vez que é uma produção literária feita por uma mulher afrocolombiana que evidencia

\footnotetext{
3 Do original: La autora le canta a su tierra, a su gente y reivindica el lenguaje coloquial del Litoral Pacifico a la vez que enriquece el verso con el ritmo y la musicalidad de los vocablos de sabor africano"

4 Esta investigação fará uso do termo afrodescendentes levando em consideração que "O estudo de afrodescendentes enfrenta muitos desafios, começando pela falta de concordância, entre vários países e mesmo dentro do mesmo país, sobre quem é ou não afrodescendente. O termo, adotado pela primeira vez por organizações regionais de afrodescendentes no início dos anos 2000 , descreve pessoas unidas por uma ancestralidade comum, mas vivendo em situações muito distintas, que incluem desde comunidades afroindígenas (como os garifunas da América Central) até grandes segmentos da sociedade tradicional (como os pardos do Brasil). Os termos negro, moreno, pardo, preto, zambo e crioulo, entre muitos outros, são muito mais próximos à compreensão latino-americana de raça e relações raciais. Muito frequentemente, essas categorias trazem estigmas e vieses derivados de uma longa história de discriminação e racismo" (BANCO MUNDIAL, 2018, p. 14-15).
} 
a defesa de sua condição quanto afrodescendente.

Para tanto, a investigação adentrará para uma análise mais aprofundada do poema "Negra soy" $(2008)^{5}$, ressaltando o destaque feito pela autora de sua identidade enquanto mulher negra na sociedade colombiana buscando evidenciar uma visão feminina na literatura, e marcando o momento em que as mulheres iniciam o seu protagonismo na literatura colombiana, permitindo observar que a escrita feita por mulheres afrodescendentes é uma maneira de manter viva a história e a identidade étnico-racial desse grupo. Assim como a produção poética é um instrumento de orgulho dos afrodescendentes, e resistência ante a sociedade que considera o individuo branco como padrão de ser humano "ideal" e um meio para a valorização da sua ancestralidade.

Uma vez que, é perceptivel que a autora em suas obras busca comunicar-se com o afrodescendente e, especificamente nesta produção poética, evidencia a autoafirmação de uma mulher que tem orgulho de sua raça e de sua identidade. Caracterizando-a como uma poesia universal, ainda que notório a valorização de sua região, a poeta caucana "relata sentir, o conjunto de tudo que vê e retrata, o seu traço cultural, sua relação com a natureza, traduz o que o afrodescendente guarda e revela nas considerações de sua religião e de sua relação com a natureza e no trato com sua cultura" (PINTO, 2016, p. 185), aspectos que enriquecem os seus poemas, mas sem esquecer da história dos enfrentamentos e da resistência, que são marcas do povo afrocolombiano.

Em seus poemas, Grueso destaca também a religiosidade, a cultura e, ainda, a beleza da região do Pacifico, que contribuem para enriquecer seus textos, bem como contribuem para a defesa da negritude e da ancestralidade negra que auxiliam para fortalecer a identidade do povo, que pertence à etnia negra, principalmente das mulheres da região.

Em termos metodológicos, faremos uma pesquisa de caráter bibliográfico que utilizará como suporte reflexões de referência retiradas, principalmente, do meio eletrônico, tais como, livros, teses, artigos e outros. Em virtude da escassa quantidade de materiais que circulam na América Latina, fez-se necessário a utilização de apuds. Para tanto, como suporte teórico serão utilizados os autores como, Espitia (2012), Palmeira (2012) e Zamorano e Escobar (2008), dentre outros.

\section{Mary Grueso Romero}

Mary Grueso Romero nasceu em 1947, em Guapi, Cauca, porém, atualmente, vive em Buenaventura, Valle del Cauca. É filha de Wilfredo Grueso e Eustaquia Romero Nicanor. Neta de escravizados, esse passado é o principal conteúdo de suas obras. Sua infância foi ao lado de seu avô, Martín Romero. É licenciada em Espanhol e Literatura, pela Universidad del Quindio, onde também recebeu o título de especialista em Enseñanza de la Literatura. Pela Universidad Los Libertadores, em Bogotá, obteve o título de especialista en Lúdica y Recreación para el Desarrollo Social y Cultural, além de outras titulações. Atualmente é docente em Buenaventura. Grueso é escritora, narradora oral, poeta etc., seus principais livros são: El otro yo que si soy yo: poemas de amor y mar (1997), Del baúl a la escuela (2003), El mary tú (2003), Negra soy (2008) e o disco compacto: Mi gente, mi tierra y mi mar (2008).

Entre os anos 2005 a 2017 foi uma figura catedrática de literatura na Universidad del Valle, sede Pacífico. Já em 2008, ofereceu oficinas de oralidade na Universidad Libre, de Cali e, há cinco anos, vem desenvolvendo oficinas de promoção de leitura e conferências na Biblioteca del Banco de la República, na Universidad del Valle na Universidad del Pacífico. Mary também foi presidenta e vice-presidenta do Consejo de Literatura del departamento del Valle del Cauca e auxilia anualmente o Encuentro de Mujeres Poetas Colombianas, do Museo Rayo, em Roldanillo, Valle del Cauca (ZAMORANO; ESCOBAR, 2008, p. 155).

É considerada uma das vozes mais fortes do Pacífico Colombiano e, por isso, recebeu,

5 O poema "Negra soy" faz parte do livro El otro que yo que si soy yo - Poemas de amor y mar" de (1997). para tanto, esta investigação utilizada o texto publicado na antologia colombiana iNegras Somos!: Antologia de 21 Mujeres Poetas Afrocolombianas de la Región Pacifica (2008), de Guiomar Escobar e Alfredo Zamorano (ROMERO, 2008 apud ZAMORANO; ESCOBAR, 2008, p. 157-158). 
em 1997, o reconhecimento como a primeira mulher poeta consagrada do Pacífico caucano, outorgado pela Normal Nacional. Em 2007, foi eleita como a Mulher do Ano no aspecto literário, pela Universidad Santiago de Cali e da Mejor Maestra, pelo Proyecto Etnoeducativo, concedido pela Secretaría de Educación del Valle del Cauca. Recebeu como homenagens, documentários sobre sua vida e obras, os quais ressaltam a importância do seu papel como mestre e poeta, pela cadeia de televisão Señal Colombia, no ano 2007 e no programa de televisão Por qué creer en Colombia (ZAMORANO; ESCOBAR, 2008, p. 155156), retratando-a nos documentários como uma das pessoas de maior reconhecimento neste país.

Mary Grueso, mulher negra que traz a representatividade de seu povo, que tenta conectar com todas as mulheres afrodescendentes os seus pensamentos e a defesa da identidade étnico-racial, na poesia "Negra Soy", apresenta a mulher pacífica de sua região, exaltando a mulher negra que não rejeita a sua raça e muito menos a sua cor, que é muito valorizada em seus escritos, apresentando uma mulher que se orgulha de ser o que é, que conhece a sua história e que retrata as mulheres por meio de sua voz, independentemente de sua classe social.

Quanto a sua trajetória poética, em 1993, a Universidad del Quindio realizou um concurso de poesia, no qual ela obteve o primeiro lugar, iniciando nesse momento a sua carreira poética, pois observou que a literatura seria uma oportunidade para falar de sua terra, de sua gente, do Pacifico e dos outros descendentes como ela. Neste sentido, María Mercedes Jaramillo, esclarece que:

Nos versos de Mary Grueso Romero se misturam a alegria e a dor, o humor e a tragédia para explicar os altos e baixos da existência e da experiência vital dos habitantes do Litoral; seus poemas mostram a força espiritual dos afrocolombianos que não perdem o desejo de desfrutar a vida apesar da discriminação e do abandono da região por parte do Estado ${ }^{6}$ (JARAMILLO, 2005, p. 2, tradução nossa).
Como narradora oral, em 1994, no "Encuentro de contadores de historias y leyendas", em Buga, ela apresentou seus contos, mitos e lendas, os quais foram bases para tradição oral da população do Pacífico Colombiano na literatura. Essa experiência permitiu a sua inserção em diferentes universidades de Cali.

Além de mestre e poetisa, dedicou-se a escrever para crianças. Essa necessidade surgiu como estratégia pedagógica: escrevia contos para os alunos de primeiro ao quinto grau da educação básica primária, o que resultou em um número significativo de contos infantis. Sobre este aspecto ela afirma que:

Eu sempre gostei de trabalhar na escola primária, pois considero que é onde são plantadas as bases da formação das pessoas. "Consultando obras literárias, só encontrei um conto de crianças negras, chamada" La niña bonita", e então vi a necessidade de penetrar na literatura infantil colombiana, introduzindo contos de crianças negras ilustradas, para que essas crianças negras se vejam refletidos nos contos que lêem ${ }^{7}$ (ROMERO, 2013 apud BRYAN; VICTORIA, 2013. p. 11, tradução nossa).

Osorio (2015) afirma que quanto aos escritos infantis de Mary Grueso, esses possuem a finalidade de deslegitimar tudo que abarca o imaginário racial discriminador, desta maneira:

A autora, como professora experiente, conhece muito bem os dilemas enfrentados pelos meninos e meninas do Litoral, pois o processo escolar tradicional propõe o branqueamento como indispensável para romper as barreiras da pobreza e da marginalidade. É importante apontar que a obra de Grueso Romero está direcionada especialmente à população infantil negra. As múltiplas edições do conto "Muñeca Negra" e sua ampla recepção entre a população afro do Pacífico indicam a necessidade de construir modelos capazes de enfrentar a homogeneização cultural. A mesma autora destacou que essas narrações se referem às memórias de sua infância, momentos situados em meados do século $X X$, quando esse território ainda não estava sob a pressão dos discursos desenvolvimentistas próprios da década de $90^{8}$ (OSORIO, 2015, p. 152, tradução nossa).

\footnotetext{
6 Do original: En los versos de Mary Grueso Romero se mezcla la alegría y el dolor, el humory la tragedia para dar cuenta de los altibajos de la existencia y de la experiencia vital de los habitantes del Litoral; sus poemas muestran la fuerza espiritual de los afrocolombianos que no pierden el deseo de disfrutar la vida a pesar de la discriminación y el abandono de la región por parte del Estado..

7 Do original: Siempre me gustó trabajar en primaria, pues considero que es alli donde se plantan las bases de la formación de las personas". "Consultando obras literarias, solo encontré un cuento de niños negros, llamado "La niña bonita," y entonces vi la necesidad de penetrar en la literatura infantil de Colombia, introduciendo cuentos de niños negros ilustrados, para que esos niños negros se vean reflejados en los cuentos que leen.
}

8 Do original: La autora, como maestra experimentada, conoce muy bien los dilemas con los que deben enfrentarse los niños y las niñas 
Seus textos, sob um carácter educativo, são utilizados nas escolas como parte de projetos de leitura para promover processos de inclusão do afrodescendente no espaço social, enfatizando a diferença como afirmação e construção da identidade desse grupo. Bem como, buscam despertar na população infantil o orgulho de pertencer a identidade étnico-racial negra, mantendo a memória e reconhecendo-se como afrodescendentes.

\section{Mary Grueso Romero e a Literatura afrocolombiana}

São inúmeras as histórias que remetem à África através de variados temas vistos nos livros, documentários e filmes. São histórias da vida de um povo que não possuía voz e, em diversos casos, sofriam com relatos distorcidos de suas vidas que se proliferaram pela sociedade. Diante disso, o presente texto evidencia a forte presença e contribuição cultural dos afrodescendentes na América do Sul, especificamente, na Colômbia. No entanto, vale ressaltar que a poesia colombiana apresenta duas características segundo Montealegre (2011, p. 219 , tradução nossa): "[...] a primeira delas foi seu tom grandiloqüente; a segunda, a presença do rural como um referente nostálgico9".

No campo literário, a relação entre literatura e afrodescendência vem desde o período escravocrata, de acordo com Palmeira (2012, p. 249), "os negros escravizados recorriam à poesia e aos cantos orais para registrar a memória histórica e as culturas africanas". Entretanto, esse tipo de literatura era feita, em grande parte, por autores negros.

Para tanto, Espitia chama atenção para a ausência de critérios específicos que definam o conceito de literatura afrocolombiana, uma vez que essa, na maioria dos casos, é caracterizada como todas as produções literárias de escritores afrodescendentes ou que pertencem a etnia negra, sem a preocupação se elas compartilham elementos comuns ou se buscam pertencer a uma mesma expressão literária a partir de uma mesma ideologia (ESPITIA, 2012, p. 1-2). Dessa maneira, por não haver uma concepção que leve a um entendimento claro sobre a literatura afrocolombiana, continuarão sendo escritas obras sob este termo.

Por outro lado, a literatura afrocolombiana como um feito social ganha espaço e de acordo com Valero (2013):

[...] há contado com um crescimento no número de escritores, enquanto outros, mais antigos, começaram a ser recuperados com maior intensidade. Se determinadas histórias antes ignoradas conseguem ser incorporadas e naturalizadas, é necessário submetê-las a uma análise de desmantelamento e desnaturalização porque sua interpretação só será possivel se conhecermos o regime de significado em que elas se movem ${ }^{10}$ (VALERO, 2013, p. 24-25. tradução nossa).

É necessário que o conceito de literatura afrocolombiana esteja em consonância com uma proposta estética que engloba o mundo do afrodescendente, a sua identidade como um sujeito que possua uma cultura própria, assim como contribua para a construção sócio-histórica do meio ao qual pertencem, como evidencia Alaix (2001): "[...] o afrocolombiano faz desde sua própria língua, mas não sob a estrutura de alguma linguagem africana; nem as requerem para a sua criação poética, e para falar de sua raça, de seu espaço e de suas práticas culturais, ter vivido na África, embora a tenham internalizado"11." (ALAIX,

\footnotetext{
de Litoral, ya que el proceso escolar tradicional propone el blanqueamiento como indispensable para romper los cercos de la pobreza y de la marginalidad. Es importante señalar que la obra de Grueso Romero está dirigida especialmente a la población infantil negra. La múltiples ediciones del cuento "Muñeca negra" y su amplia recepción entre la población afro del Pacifico indican la necesidad de construir modelos capaces de enfrentar la homogeneización cultural. La misma autora ha señalado que estas narraciones se refieren a memorias de su infancia, momentos situados a mediados del siglo XX, cuando todavía este territorio no estaba bajo la presión de los discursos desarrollistas propios de la década de los 90

9 Do original: [...] la primera de ellas fue su tono grandilocuente; la segunda, la presencia de lo rural como un referente nostálgico [...].

10 Do original: [...] ha contado con un crecimiento en el número de escritores, mientras que otros, más antiguos, comenzaron a ser recuperados con mayor intensidad. Si determinadas historias antes ignoradas logran ser incorporadas y naturalizadas, es necesario someterlas a un análisis de desmonte y desnaturalización porque su interpretación solo será posible si conocemos el régimen de sentido en el que se mueven.

${ }_{11}$ Do original: [...] el afrocolombiano la hace desde su propia lengua, más no bajo la estructura de algun lenguaje africano; tampoco han requerido para su creación poética, y para hablar de su raza, de su espacio y de sus prácticas culturales, haber vivido en África, aunque sí la han interiorizado.
} 
2001 apud ESPITIA, 2012, p. 8, tradução nossa).

Tendo em vista estes aspectos, Espitia (2012) ao perceber a ausência de uma compreensão a respeito desse tipo de escritura, propõe uma definição, de uma forma simples, que a literatura afrocolombiana é entendida como:

[...] o conjunto de produções orais e escritas que colocam se manifesto os valores e os sentimentos próprios de um individuo afrocolombiano, que se reconhece dentro de um grupo étnico com quem compartilha uma concepção epistêmica de seu ser afrodescendente e uma história comum, e através da qual representa elementos próprios de sua identidade, idiossincrasia e seus costumes ${ }^{12}$ (ESPITIA, 2012, p. 13-14, tradução nossa).

Contudo, a literatura afrocolombiana corresponde a obras produzidas por homens e mulheres afrodescendentes, incluindo toda poesia, narrativa e teatro produzido, na grande maioria dos casos por afrocolombianos, os quais buscam estabelecer uma conexão histórica com o pais de seus ancestrais, a África, preservando a sua ancestralidade requerendo o reconhecimento de sua identidade e utilizando de maneira criativa a linguagem, como forma de libertarse da opressão cultural advinda da opressão física de seus ascendentes durante o periodo da escravidão. Assim, Valero (2013) esclarece que:

Em outras palavras, a categoria "literatura afrocolombiana" se beneficia pela existência de um público receptor que pode absorver e, além disso, fomentam esse campo significativo na medida em que é capaz de responder à codificação. Embora seja invocada como um enunciado constativo, no sentido de conter em si mesmo, em seus códigos, os aspectos que constituem uma (id)entidade, na realidade, a categoria "literatura afrocolombiana" atua como um enunciado performativo enquanto seu corpo teórico descritivo incrementa como uma estratégia de denominação, isto é, ao tempo que fala realiza o que nomea ${ }^{13}$ (VALERO, 2013. p. 27, tradução nossa).
O poeta Candelario Obeso teve uma grande representatividade no cânone literário colombiano, além de ter sido considerado o precursor da poesia negra, definida como: "[...] a expressão poética de um indivíduo que se vê e se identifica como membro do grupo ou povo negro sem deixar de manter e afirmar na obra sua própria individualidade ${ }^{14 " ~(P R E S C O T T, ~}$ 1985 apud VALERO, 2013, p. 22, tradução nossa). Quanto à denominação afrocolombiano, a mesma não era conhecida dessa forma, uma vez que tal denominação vem sendo incorporada ao ambiente educacional somente nos últimos anos, após o crescente número de trabalhos com foco nesse assunto (VALERO, 2013, p. 2). Sobre isso, Pinto (2012) acrescenta que, "[...] a junção desses dois termos configura-se ao suscitar que, de fato, esses elementos remetem de outrora a identidade do negro colombiano" (PINTO, 2012, p. 188).

Vale ressaltar que o termo afro foi proposto por Roger Bastide, no Brasil, na década de 1970. Era utilizado para analisar os fenômenos culturais dos povos negros. No entanto, a terminologia afrocolombiano foi adotada anos depois com o surgimento da Lei . $^{\circ}$ 70, de 1993, a fim de reconhecer os direitos das comunidades negras rurais do Pacíico

A Lei 70 concedeu às comunidades negras o direito de posse de seu território coletivo, bem como o direito de manterem suas economias tradicionais baseadas no meio rural e de se desenvolverem de maneiras compativeis com suas identidades culturais e práticas sociais. Ela também determinou a inclusão da história e da cultura afro-colombianas nos currículos das escolas públicas. Por fim, ela reservou dois assentos no Congresso Nacional e mais de 300 cargos públicos para membros das comunidades negras. Tal reforma constitucional foi possivel devido ao ativismo dos movimentos sociais afrodescendentes (BANCO MUNDIAL, 2018, p. 44).

\footnotetext{
12 Do original: [...] el conjunto de producciones orales y escritas que ponen de manifiesto los valores y los sentimientos propios de un individuo afrocolombiano, quien se reconoce a si mismo dentro de un grupo étnico con quien comparte una concepción epistémica de su ser afrodescendiente y una historia común, y a través de las cuales representa elementos propios de su identidad, su idiosincrasia y sus costumbres.

13 Do original: En otras palabras, la categoria "literatura afrocolombiana" se beneficia por la existencia de un público receptor que puede absorber y, además, retroalimentar ese campo significante en la medida en que es capaz de responder a la codificación. Aunque se la invoque como un enunciado constatativo, en el sentido de contener en sí, en sus códigos, los aspectos que hacen a una (id)entidad, en realidad, la categoria "literatura afrocolombiana" actúa como un enunciado performativo en cuanto su cuerpo teórico descriptivo se retroalimenta como estrategia de denominación, esto es, al tiempo que habla realiza lo que nombra.

14 Do original: [...] la expresión poética de un individuo que se ve y se identifica como miembro del grupo o pueblo negro sin dejar de mantener y afirmar en la obra su propia individualidad.
} 
Portanto, a Lei tinha o intuito de trazer visibilidade às comunidades afrodescendentes e os seus valores culturais, assim como assegurar os direitos destes sujeitos em condição de igualdade frente a população colombiana como um todo (ESPITIA, 2012, p. 4), dessa maneira, conforme define a Cátedra de estudos Afrocolombianos:

O prefixo afro refere-se à herança cultural africana que sobrevive na memória coletiva através de diferentes saberes e práticas, principalmente na tradição oral, na memória corporal, que inclui gestos, dança, palavras, arte, música, os cantos, e sua relação com a natureza. É o passado ancestral, elemento chave de sua identidade étnica hoje ${ }^{15}$ (apud ESPITIA, 2012, p. 4, tradução nossa).

Para tanto, Pinto (2016) afirma que:

É por meio dessas prerrogativas que as considerações do vocábulo "afro" se pré-estabelecem, e a "colombianidade" é remetida neste texto. A junção desses dois termos configura-se ao suscitar que, de fato, esses elementos remetem de outrora a identidade do negro colombiano. Identidade essa que se constrói dentro da junção, das contribuições, de: crenças espirituais, do trabalho braçal, do desenvolvimento e resistência dos negros no Novo Mundo que gerou a realidade do que essa gente é hoje, ou seja, o conjunto patrimonial imaterial que é tudo isso. É a constituição do ser afrocolombiano, arraigada a todo esse processo político, étnico, social, pluricultural e cheio de tantos elementos que tecem a história desse povo (PINTO, 2016, p. 187).

Anterior a esta Lei que viabiliza o termo afro, era utilizada a nomenclatura comunidades negras para denominar os estudos relacionados aos povos afrocolombianos que por meio de lutas conquistaram o direito de romper com este negativo legado, o qual foi adquirido durante o periodo colonial que os classificava segundo uma cor, o negro, passando a ser reconhecidos como descendentes de uma tradição e uma história própria que herdaram de seus ancestrais.

Com relação a Mary Grueso Romero, seus poemas são considerados um símbolo de resistência ao periodo de escravidão, pois representam um pedido de ajuda e de gritos de liberdade, no qual ressoam em suas poesias como tambores da África que os escravos recriaram para manter viva a esperança de liberdade, como afirma Águeda Pizarro Rayo (apud ZAMORANO; ESCOBAR, 2008, p. 156, tradução nossa): "Seus poemas, esculturas esculpidas por sua mente e seu coração, podem ser comparados aos tambores da África que os escravos recriaram em América, para enviar mensagens de liberdade inescrutáveis para os senhores brancos e os negreiros ${ }^{16 "}$, seus poemas constituem uma verdadeira herança cultural e servem para manter viva a memória e a identidade do povo africano.

Além disso, em seus poemas, Grueso conta a sua história e a de sua comunidade em cada verso, porém não o faz de maneira erudita, pelo contrário faz uso das variantes regionais, molda a sua arte de modo que sempre evidencie a sua identidade afrodescendente, para tal, revive em suas estrofes os cantos, as danças, os rituais e as crenças de sua comunidade, isto é, as marcas de seu povo, como evidência Pinto (2016, p. 193): Sem ignorar a formas clássicas da poesia mo-
derna hispânica, ela alimenta suas poesias
dando a conhecer as variações regionais, a
geografia, os lugares da gente de sua obra e
tudo isso para mostrar a fonte: o espaço de
sua gente. Tudo remete à sua negritude [...].

Para a escritora a história de seus antepassados que foram escravizados é algo que não faz parte somente do passado. Para ela, essas marcas são reflexos em seu próprio presente, que em cada verso, são recuperados com a memória de seus avós, como uma recordação de seus antepassados que sofreram na pele a escravidão, o que qualifica a literatura feita por Mary Grueso como literatura afrocolombiana. Isso porque, conforme a definição de Espitia, trata-se de uma produção que apresenta os elementos próprios de um sujeito que se reconhece como afrocolombiano dentro de um

\footnotetext{
15 Do original: El prefijo afro hace referencia a la herencia cultural africana que pervive en la memoria colectiva a través de distintos saberes y prácticas, sobre todo en la tradición oral, la memoria corporal, que incluye gestos, la danza, las palabras, el arte, la música, los cantos, y su relación con la naturaleza. Es el pasado ancestral, elemento clave de su identidad étnica hoy.

16 Do original: Sus poemas, esculturas talladas por su mente y su corazón, se pueden comparar a los tambores de África que los esclavos recrearon en América, para enviarse mensajes de libertad inescrutables para los amos blancos y los negreros.
} 
grupo étnico, a partir de uma história comum que apresenta caracteristicas especíicas, como a sua identidade, a idiossincrasia que distingue o povo afrocolombiano dos demais, além dos costumes.

No poema "Negra soy", a autora trabalha com a consciência de ser uma mulher negra descendente de individuos escravizados, contudo, isso não sucede excepcionalmente nessa obra, mas em todas as suas manifestações, sejam elas orais ou escritas. Grueso se preocupa em ressaltar a raça a qual pertence, pois possui orgulho de suas raizes, todavia, em suas poesias não aborda somente esses aspectos, visto que faz de sua escrita um manifesto, onde simboliza a luta diante da sociedade que ainda conserva uma visão de preconceito criada no período de escravidão contra os escravizados e, ainda, presente na atualidade, principalmente, com a mulher negra afrodescendente. Por isso, sua poesia pode ser definida como um protesto em forma de versos.

Assim, Mary Grueso traz em suas escrituras marcas culturais que representam uma forte ligação com seu povo, com as tradições, com a identidade afrodescendente que traz para os seus poemas uma força expressiva, fazendo com que os leitores sejam atraidos as suas obras. A autora é uma voz afrofeminina que narra o orgulho de ser negra, uma voz que ressoa a resistência e a identidade africana.

\section{Autoria feminina na literatura afrocolombiana: a mulher negra que escreve sobre a sua condição}

Os afrodescendentes partindo da necessidade de reescrever a sua história, buscavam dar visibilidade a sua cultura, a sua história, a sua religião, assim como as diversas contribuições desse grupo para a construção sócio-histórica da América, já que as histórias oficiais e nacionais sempre foram relatadas pelo outro, na grande maioria das vezes, pelos brancos.

Diante disso, e buscando visibilidade, o afrodescendente torna-se sujeito do discurso narrando as suas memórias, sob a responsabilidade de resgatar os esquecimentos pelos quais foram submetidos. Para tanto, a memória consiste em "um dos instrumentos de resistência cultural utilizados pelos escritores e escritoras da diáspora africana. Escrever sobre as memórias e culturas negras torna-se uma forma de narrar o relato sob a ótica afrodescendente" (PALMEIRA, 2013, p. 96). E a literatura foi um dos principais meios para difundir a memória afrodescendente, assim como

A literatura é chamada a demonstrar não somente grandes ausências históricas, mas também as presenças turvas e maltratadas dos africanos ao redor do mundo. Essas imagens obscuras e remotas da realidade foram refletidas por anos nas literaturas ocidentais. Imagens que ainda hoje persistem, embora em menor escala, em alguns de nossos paises ${ }^{17}$ (BARR, 2009, p. 37, tradução nossa).

\section{De acordo com Campos,}

[...] as mulheres sempre foram excluidas da história, sendo a mulher negra duplamente excluida. [...] Ao longo dos tempos o que sempre se vê em relação à mulher afrodescendente é sua imagem escrava, usada para a prática de sexo fácil, ou ainda [...], no papel da doméstica (CAMPUS, 2013 apud MOTTA; BOTH, 2016, p. 162).

Por esse motivo, Santos (2009, p. 5) evidencia que as mulheres negras, precisam recuperar a sua identidade, de forma que consigam valorizar a sua história, assim como as suas raízes, assumindo-se enquanto afrodescendentes e sujeitos ativos no desenvolvimento do processo de democratização racial.

Mas ao longo da história literária, em um grande número de obras, os afrodescendentes eram apresentados como personagens secundários. Ao falar desses exercendo o papel de escritores, somente é possivel constatar tal acontecimento na literatura colombiana no período da República, como evidencia Alain Lawo-Sukam (2011, p. 51, tradução nossa): "Não foi até os alvorecer da República que a literatura escrita afrocolombiana entra no mundo das letras nacionais ${ }^{18 " .}$ 
Todavia, tal presença era sempre invisivel, principalmente em relação às mulheres, uma vez que os primeiros estudos relacionados à literatura afrocolombiana eram considerados produções feitas por homens afrodescendentes, apesar disso existiam textos literários produzidos por essas, porém não recebiam a devida importância como observa Laurence Prescott em seu texto "Perfil histórico del autor afrocolombiano: perspectivas y problemas", onde o autor aponta que "no entanto, é preciso apontar que entre a lista de autores negros que figuram na literatura colombiana, não aparece nomes feminino19" (PRESCOTT, 1996, p. 557, tradução nossa).

O surgimento e a valorização da escrita afrofeminina iniciou com a publicação do marco para a literatura afrodescendente da Colômbia, a primeira antologia de escritoras afrocolombianas intitulada iNegras Somos!: Antología de 21 Mujeres Poetas Afrocolombianas de la Región Pacífica (2008), construida pelos escritores Guiomar Escobar e Alfredo Zamorano, produção que tinha como finalidade apresentar aos colombianos as obras de 21 escritoras afrocolombianas, além do desejo de preencher o vazio diante da invisivel presença das poetas negras na produção literária feita na Colômbia. Uma das escritoras que se destacou a partir desta antologia foi Mary Grueso Romero, assim os autores mencionados acima, enfatizam que:

Com isso, em nossa opinião, demonstra-se como nem a poesia, nem a ciência, nem qualquer área da criatividade e do conhecimento humano, são de propriedade exclusiva de um único país, nem de um único gênero. Nem exclusividade de um único grupo étnico, ou de uma só classe ou estrato socio-econômico. Com a força de sua presença, com seus poemas, com suas apresentações em vários fóruns, esses grupos de mulheres afrocolombianas estão nos dando uma lição muito importante que devemos levar em consideração e destacar diante de toda a Colômbia, como também fora do nosso paísº (ZAMORANO; ESCOBAR, 2008, p. 15, tradução nossa).

Para tanto, apesar da invisibilidade imposta às escritoras negras até então, isso não as impediu de escreverem e exporem os seus textos em eventos literários e culturais, bem como publicálos. E tais movimentos, permitiram observar como a autoria feminina marca o momento em que as mulheres iniciam o seu protagonismo na literatura colombiana e o reconhecimento de suas raizes, a partir dos seus discursos que assumem uma identidade afrocolombiana.

Aspecto este que pode ser identificado no poema "Negra soy", objeto de estudo desta investigação, que será analisado em seguida. No qual, segundo a mesma autora, o sujeito poético feminino defende o seu direito de ser nominada socialmente de negra, construindo uma contraposição entre os termos negra versus morena/de color, bem como estabelece uma relação entre a identidade étnicoracial e a memória do grupo ao qual pertence, evidenciando aspectos como a ancestralidade africana e a luta contra a escravidão.

Antes de adentrar a essa questão é necessário mencionar a presença de outras escritoras afrodescendentes na literatura afrocolombiana, que escrevem sobre a sua condição de mulher negra em uma sociedade marcada sob a desigualdade de gênero, a qual encontra-se baseada na seguinte visão, segundo destaca Lozano e Peñaranda (2017):

As diferenças criadas pela sociedade capitalista, branca e patriarcal têm subordinado e discriminado as mulheres negras por não serem iguais ao sujeito para os quais foram feitos os direitos do cidadão: varão, branco, adulto, proprietário... Essas diferenças excluiram, marginalizaram e tornaram invisiveis por serem mulheres, negras, indigenas, camponesas, pobres... Historicamente, isso significa não estar sujeitas a direitos, estar localizadas além da periferia e que nossa identidade foi construida pelo dominador com base em estereótipos acerca da nossa sexualidade, nossa corpo e nossa cultura. As mulheres negras são vistas como excelentes cozinheiras, melhores amantes e extraordinárias dançarinas. As mulheres negras e a população negra em geral são vistas a partir de uma folclorização de sua cultura; [...]

\footnotetext{
19 Do original: no obstante, es preciso señalar que entre la nómina de autores negros que figuran en la literatura colombiana, no aparecen nombres femeninos.

20 Do original: Con ello, a nuestro parecer, se demuestra cómo ni la poesía, ni la ciencia, ni ninguna área de la creatividad y del conocimiento humano, es posesión exclusiva de un solo país, ni de un solo género. Ni exclusividad de un solo grupo étnico, o de una sola clase o estrato socioeconómico. Con la fuerza de su presencia, con sus poemas, con sus presentaciones en diversos foros, estos grupos de mujeres afrocolombianas nos están dando una lección muy importante que debemos tener en cuenta y destacar ante toda Colombia como también fuera de nuestro pais.
} 
mulheres exóticas com quadris grandes, [...]. Se desconece o aporte substancial da população negra a construção do país, as lutas pela independência, as artes, a ciência ${ }^{21}$ (LOZANO; PEÑARANDA, 2017, p. 416-417, tradução nossa).

Sob esse estigma a autoria feminina negra se constitui como um espaço de representação, por meio da escrita e do poder da palavra, que proporciona visibilidade a sua condição, suas denúncias frente aos estereótipos atribuídos a essa no espaço social, o resgate à memória, o orgulho de ser mulher negra, assim como celebra a cultura afrocolombiana em seus escritos, já que "A partir de suas identidades de mulheres negras na sociedade colombiana, essas escritoras apresentam um discurso que constrói e assume uma identidade feminina afrocolombiana" (PALMEIRA, 2012, p. 253), que igualmente contribui para o fortalecimento da identidade negra ao retomar a memória desse grupo, seus sofrimentos e assujeitamentos, bem como a sua luta e resistência de maneira ficcional.

Vale ressaltar o reconhecimento de algumas autoras como, María Teresa Ramírez, licenciada em História e Filosofia pela Universidad del Valle (1967), professora e escritora, que em 2007 por alcançar excelência em sua obra poética recebeu o prêmio Almanegras. Apresenta na antologia iNegras Somos!: Antologia de 21 Mujeres Poetas Afrocolombianas de la Región Pacífica, no poema "Canto Mágico" a relação entre a memória de seus ancestrais e a figura das avós, como mulheres que procuram transmitir aos seus netos todo o conhecimento adquirido a partir de suas raízes africanas (PALMEIRA, 2012, p. 254). Assim como, Ofelia Margarita Benet Robinson, Leida Viveros Vigoya, Imelda Mina Díaz, Amalia Lú Posso Figueroa, Ana Teresa Mina Díaz, nascidas na década de 1940 (ZAMORANO; ESCOBAR, 2008, p. 113-184).

Outras autoras que também ganharam destaque com a referida antologia e são consideradas pioneiras, nascidas antes da década de 1940 , são nomes como Teresa Martínez de Varela, Luz Colombia Zarkanchenko de González, Elisa Posada de Pupo, Bertulia Mina Díaz, Lucrecia Panchano, até as escritoras da década de 1980, como Nena Cantillo Atuesta, Kenia Martínez Gómez, Mayra Alejandra Sierra Ruiz, Sindy Cardona Cuello (ZAMORANO; ESCOBAR, 2008, p. 71-590), que possuem em comum o fato de que todas são "mulheres poetas afrodescendentes colombianas do pacífico" (PALMEIRA, 2012, p. 252), apesar de escreverem a partir de estilo e contextos diferentes.

\section{A voz afrofeminina no poema Negra Soy: orgulho, identidade, resistência}

O poema "Negra soy", do livro El otro que yo que sí soy yo - Poemas de amor y mar (1997), a autora Mary Grueso fala de seu orgulho em sentirse e conhecer-se como negra, de suas raízes africanas, da luta de seu povo pela liberdade. Antes vejamos o poema na integra:

\author{
Negra soy \\ ¿Por qué me dicen morena? \\ Si moreno no es color, \\ yo tengo una raza que es negra \\ y negra me hizo Dios. \\ Y otros arreglan el cuento \\ diciéndome de color \\ dizque pa' endúlzame la cosa \\ y que no me ofenda yo. \\ Yo tengo mi raza pura \\ y de ella orgullosa estoy, \\ de mis ancestros africanos \\ y del sonar del tambó. \\ Yo vengo de una raza que tiene \\ una historia pa' contá \\ que rompiendo sus cadenas
}

21 Do original: Las diferencias creadas por la sociedad capitalista, blanca y patriarcal nos han subordinado y discriminado a las mujeres negras por no ser iguales al sujeto para quienes fueron hechos los derechos del ciudadano: varón, blanco, adulto, propietario... Estas diferencias nos han excluido, marginado e invisibilizado por ser mujeres, negras, indígenas, campesinas, pobres... Históricamente, esto ha significado no ser sujetas de derechos, estar ubicadas allende la periferia y que nuestra identidad haya sido construida por el dominador con base en estereotipos acerca de nuestra sexualidad, nuestro cuerpo y nuestra cultura. Las mujeres negras somos vistas como excelentes cocineras, mejores amantes y extraordinarias bailarinas. Las mujeres negras y la población negra en general son vistas a partir de una folclorización de su cultura; [...], mujeres exóticas de caderas grandes, [...]. Se desconoce el aporte sustancial de la población negra a la construcción del pais, a las luchas de independencia, a las artes, a la ciencia. 
alcanzó la libertá.

A sangre y fuego rompieron,

las cadenas de opresión

y ese yugo esclavista

que por siglos nos aplastó.

La sangre en mi cuerpo

se empieza a desbocá,

se me sube a la cabeza

y comienza a protestá.

Yo soy negra como la noche,

como el carbón mineral,

como las entrañas de la tierra

y como el oscuro pedernal.

Asi que no disimulen

llamándome de color,

diciéndome morena,

porque negra es que soy yo.

(ROMERO, 2008 apud ZAMORANO; ESCOBAR, 2008, p. 157-158)

Grueso evidencia que, apesar de sua raça ter sido na história da humanidade um personagem secundário no periodo da escravidão, e que ainda continua a ser esquecido pelo preconceito e pelo racismo, é uma raça que tem uma história e uma identidade que resistiu ao tempo, através da memória deste povo, onde pode ser observado nos seguintes versos de seu poema: "Yo tengo mi raza pura/ y de ella orgullosa estoy, [...] Yo vengo de una raza que tiene/ una historia pa' contá/ que rompiendo sus cadenas/ alcanzó la libertá" (ROMERO, 2008 apud ZAMORANO; ESCOBAR, 2008, p. 158).

Grueso relata a sua memória individual, que na verdade, está ligada a uma proporção coletiva, entendida por Souza (2016) como "memória individual-coletiva de Mary Grueso Romero", que segundo ele contribui para a compreensão, assim como para a desconstrução de ideologias consideradas hierarquizantes, porque a escritora caucana celebra em seus textos a diversidade, preenchendo os vazios e as distorções produzidas pela história considerada oficial, da mesma forma que abre espaços na literatura para apresentar o que significa ser afrocolombiano para as comunidades do Afro Pacíico (SOUZA, 2016, p. 43).

A autora também descreve em seus poemas o sentimento de orgulho por ser uma mulher negra. Em virtude disso, Palmeira (2012, p. 254) elucida que:

\begin{abstract}
Ao longo do poema, é apresentado um eu poético feminino que afirma e defende seu direito de ser socialmente denominada de negra. Vale ressaltar que este sujeito poético estabelece uma relação entre a identidade étnico-racial e a memória de tal grupo. Os elementos enumerados para justificar o orgulho de tal pertencimento étnico-racial são elementos que constituem a memória desse grupo: a ancestralidade africana e a alusão a luta contra escravidão [...].
\end{abstract}

Outro elemento presente na construção poética é a comparação feita entre a sua identidade étnico-racial e os elementos da natureza, como a escuridão da noite do carvão, das entranhas da terra, e como o pedernal, que é um tipo de quartzo. Eles representam a essência do afrodescendente: estão em constante contato com a natureza, como se fossem uma extensão dela, e ela, a representação perfeita de ser negra, já que "A natureza é muito valorizada pelo povo negro (afrodescendente), com destaque nas religiões de matrizes africanas que constituem seus orixás protegendo seus elementos" (PINTO, 2016, p. 189), essa harmonia pode ser observada no trecho, "Yo soy negra como la noche,/ como el carbón mineral,/ como las entrañas de la tierra/ y como el oscuro pedernal." (ROMERO, 2008 apud ZAMORANO; ESCOBAR, 2008, p. 158).

No poema, a escritora não refere-se somente do orgulho dos afrodescendentes, mas também chama atenção para a construção de sua identidade, uma vez que estes são nomeados na sociedade de distintas maneiras. No texto é usado o termo morena, o qual serve socialmente para designar a sua etnia, mas a autora afirma não ser um vocábulo correto, pois moreno não é cor, e portanto, não define a sua afrodescendência. No entanto, evidência que deve ser nomeada com a palavra negra, mesmo porque Deus a fez desta forma, então, deve ter orgulho de sua cor e ser respeitada. Com isso, reafirma a sua identidade étnico-racial como descendente de escravos, 
uma vez que, segundo "a categoria negra é associada a uma reivindicação da identidade negra ao passo que morena/ de color é associado a uma estratégia de branqueamento" (PALMEIRA, 2013, p. 98), como é possivel verificar no trecho "¿Por qué me dicen morena?/ Si moreno no es color, / yo tengo una raza que es negra/ y negra me hizo Dios" (ROMERO, 2008 apud ZAMORANO; ESCOBAR, 2008, p. 157).

Outro ponto importante também destacado nos poemas de Mary Grueso é a valorização da identidade negra quando descrevem os rituais de seus ancestrais, como o uso de tambores que serviam para manter viva a sua cultura enraizada, que eram praticados em suas terras, bem como para demonstrar a dor e a saudade de seu povo. Essas lembranças de suas raízes eram importantes para preservar a sua identidade étnico-racial, capaz de ser confirmado em: "Yo tengo mi raza pura/ y de ella orgullosa estoy,/ de mis ancestros africanos/y del sonar del tambó" (ROMERO, 2008 apud ZAMORANO; ESCOBAR, 2008, p. 157).

A escritora evidencia o orgulho de ser afrodescendente ao relembrar de maneira histórica e geográfica a sua ancestralidade, por meio da palavra. Refaz o percurso de saída e de chegada do continente africano e dos territórios regionais, produzindo um sentimento de pertencimento, que é entendida de modo geral por Souza como (2016, p. 49, ênfase do autor):

[...] a ancestralidade africana nos poemas de Mary Grueso Romero se apresenta como lugar de referência, a terra perdida e idealizada, um lugar que norteia e explica o sentimento comum à raça negra. Certamente, a relação com os antepassados africanos pode ser reinterpretada como uma forma de reafirmação das suas raizes identitárias. O sujeito de etnia negra, ao reivindicar o respeito à sua otredad, reafirma também o valor da sua cultura, e ressalta, ao mesmo tempo, toda a simbologia que permeia o seu mundo e os laços afetivos transculturais.

Essa produção poética é utilizada por Grueso como instrumento da resistência negra, do protesto diante da sociedade que escravizou e ainda escraviza os afrodescendentes com o preconceito. Para tanto, a autora mescla o passado e o presente, descreve o sofrimento de seus antepassados que resistiram e lutaram contra a opressão e aos abusos vividos durante a escravidão até alcançar a liberdade. Esse movimento de resistência se estabelece na relevância dada pela autora à sua ancestralidade africana, além de representar um resgate das memórias transpassadas pela escravidão (SOUZA, 2016, p. 49). Esses sofrimentos são expressos em palavras, como sangre y fuego. A opressão e os abusos que ainda convivem na sociedade atual sob a forma de racismo são denunciados pela autora quando expressa: "La sangre en mi cuerpo/ se empieza a desbocá,/ se me sube a la cabeza/ y comienza a protestá" (ROMERO, 2008 apud ZAMORANO; ESCOBAR, 2008, p. 158).

O sangue de seus ancestrais por intermédio da memória percorre por seu corpo até alcançar a sua cabeça que, através de seu olhar crítico, enfrenta e denuncia os males que marcaram e marcam o seu povo, a sua descendência e a mulher em uma sociedade com remanescentes da escravidão e marcada pelo modelo patriarcal. Barr (2009, p. 36) fala sobre a importância de escrever sobre a história de seu povo, das características de resistência da cultura de descendência negra, quando ressalta:

Somos instrumentais no processo de relatar e interpretar a história, somos responsáveis por desenhar os rostos em suas diferentes facetas, de escrever, descrever e reescrever formas corporais e, o mais importante, somos chamados a dizer, a interpretar da forma mais fidedigna possivel o viver e sentir de nossos povos $^{22}$ (BARR, 2009, p. 36, tradução nossa).

Portanto, o passado e o presente são misturados pela autora como um caminho de resistência, pois ela não esquece a história de sofrimento e de confronto dos antepassados que foram escravos, bem como reconhece que esses males ainda persistem na sociedade e, por isso, denuncia-os.

Os protestos são presentes em todo o texto, sendo que a autora critica que, como uma forma

\footnotetext{
22 Do original: Somos instrumentales en el proceso de relatar e interpretar la historia, somos responsables de dibujar los rostros en sus diferentes facetas, de escribir, describir y rescribir formas corporales y, lo más importante, somos los llamados a decir, a interpretar de la forma más fidedigna posible el vivir y sentir de nuestros pueblos.
} 
de amenizar a história, as pessoas se referem aos afrodescendentes como pessoas de cor e, esperam que não se sintam ofendidos com tal tratamento. Mary Grueso aponta isso nos seguintes versos: "Y otros arreglan el cuento/ diciéndome de color/ dizque pa' endúlzame la cosa/ y que no me ofenda yo" (ROMERO, 2008 apud ZAMORANO; ESCOBAR, 2008, p. 157). Entretanto, a autora demonstra repúdio diante da sociedade que não reconhece o mal que fez aos escravizados e os reforça até hoje.

Na última estrofe, a escritora com sua voz afrofeminina expressa todo o seu orgulho de ser afrodescendente. Em sua voz ressoa a resistência de ser negra e de sua identidade africana herdada de seus ancestrais escravos, solicitando que não a chame de cor ou morena, porque afirma que é negra. Para tanto, Souza (2016, p. 43) evidencia que o sujeito poético dos versos de Mary Grueso

[...] estabelece uma relação de identidade local e cultural juntamente com as simbologias e memória que justificam o orgulho de ser negra e representante do seu grupo social. O sentido que a escritora procura dar aos seus versos não são apenas ilustrativos na sua poética, são, principalmente, elementos que organizam e nos convidam a repensar a condição dos negros e negras na literatura e sociedade colombiana, com seus aspectos culturais e simbólicos.

Associado a esse convite de refletir a condição dos afrodescendentes, é possivel dizer que, assim como os tambores ressoavam um canto de liberdade, o último verso também representa a canção de uma mulher de ascendência africana que somente luta pela liberdade dos laços sociais do preconceito, assim como seus ancestrais lutaram pela liberdade de as correntes que os aprisionaram no passado (RAYO apud ZAMORANO; ESCOBAR, 2008, p. 156), e todo esse grito de liberdade está expresso na seguinte passagem "Así que no disimulen/ llamándome de color,/ diciéndome morena,/ porque negra es que soy yo (ROMERO, 2008 apud ZAMORANO; ESCOBAR, 2008, p. 158).

$O$ feito central que busca Grueso em seus poemas está voltado para as questões da força de seu povo, do orgulho de reconhecer-se negra, da valorização de seus ancestrais, da dor do escravizados, assim como afirma VerganaFigueroa (2017, p. 269-270, tradução nossa):

Ela (Mary Grueso) quer mostrar seu passado
e seu presente, e por esse motivo assumiu a
tarefa de fazer poesia (em versos e prosa) com
a terminologia de seu povo, implicando nisso,
todo um estudo [...] que nos mostra o negro
desde seu desarraigo, de sua terra natal, dor
arrastada por séculos [....

Dessa forma, Mary Grueso faz o leitor reconhecer os valores dos escravizados e dos afrodescendentes e a sua imensa contribuição para a construção da sociedade colombiana e, ainda, faz com que a sua voz afrofeminina seja escutada.

\section{Considerações finais}

Os afrodescendentes na história da humanidade foram por anos personagens invisiveis, principalmente, as mulheres. Mas, com as mudanças sociais, o homem afrodescendente foi ganhando espaço, pois, entre outros fatores, fez da literatura um instrumento de reconhecimento de sua etnia e, por meio disso, a mulher também ganhou o seu espaço fazendo a sua voz negra ressoar. Através da análise do poema "Negra soy", da autora do caucana Mary Grueso Romero, foi possivel esclarecer essa maneira encantadora da escrita afrodescendente, na qual apresenta o modo como as comunidades negras vivem e mantêm as suas tradições e a cultura africana herdada de seus antepassados. Bem como, conhecer a importância da escrita afrofeminina que fez com que as mulheres fossem reconhecidas na literatura colombiana, uma vez que, por muito tempo, foi associada a escritores do gênero masculino.

Analisar essas produções contribui para a compreensão do que significa ser afrodescendente, além de compreender como esse grupo social define a sua identidade étnico-

\footnotetext{
23 Do original: Ella (Mary Grueso) quiere mostrar su pasado y su presente, y por tal motivo ha tomado la tarea de hacer poesia (en verso y prosa) con la terminología de su gente, implicando esto, todo un estudio [...] que nos muestra al negro desde su desarraigo arraigado, de patria-tierra, dolor arrastrado por siglos [...]
} 
racial, que é o primeiro passo para a valorização total desse grupo étnico na sociedade. Bem como, serve para entender o papel da voz afrofeminina como instrumento de luta, de resistência das mulheres negras afrodescendentes, na qual marca o momento em que as mulheres começam o seu papel na literatura colombiana. Por essa razão, a leitura das obras de Maria Grueso e das mulheres negras, colombianas ou de outro país, leva ao reconhecimento da autoria feminina, que, contribuirá para a construção da literatura afrodescendente colombiana.

Portanto, é possivel concluir que a autora caucana é consciente da importância de conservar a memória de seu povo e a sua poesia nutrida da tradição oral, além disso que em seus versos se mesclam a alegria e a dor, e as experiências daqueles que vivem no pacifico, mostrando a força dos afrocolombianos. A autora afrocolombiana, negra, repleta de questionamentos ancestrais que transbordam de sua alma para seus escritos, Mary Grueso Romero, faz de sua obra um reduto das temáticas que suscitam o orgulho da negritude e de ser negra neta de escravos, que não esconde a sua origem e o seu passado que é triste, mas que the é fonte de inspiração e que the serve para se comunicar com quem tem semelhante história. Para ela, é como uma missão transmitir por meio de sua voz afrofeminina uma mensagem de força, de libertação do seu orgulho, de coragem, e preservando a memória daqueles que lutaram e lutam até hoje no mundo todo, os afrodescendentes.

\section{Referências}

BARR, Shirley Campbell. Asumiendo responsabilidad por la palabra. In: SAVINO, Silvia Beatriz Garcia. Las mujeres afrodescendientes y la cultura latinoamericana: identidad y desarrollo. Montevideo: Población afrodescendiente de América Latina, 2009. p. 36-41.

BANCO MUNDIAL. 2018. Afrodescendentes na América Latina: Rumo a um Marco de Inclusão. Washington, DC: World Bank. Licença: Creative Commons Attribution CC BY 3.0 IGO.

BRYAN, Francisca Mosquera; VICTORIA, Jackeline Micota. Una vida dedicada a la tradición oral del Pacífico colombiano: Mary Grueso Romero. Palabras de Griot. Rev. del Departamento de Lenguas, Lingüistica y literatura de la Universidad del Pacífico, Colombia, v. 1, n. 1, p. 7-21, 2013. https://doi.org/10.32870/mycp.v13i39.346
ESPITIA, Yesenia María Escobar et al. La génesis de la Literatura Afrocolombiana en la poesia de Candelario Obeso y Jorge Artel. 2012. 114 f. Tese (Maestría en Estudios Literarios) - Universidad Nacional de Colombia, Bogotá, 2012. https://doi.org/10.33304/ revinv.v10n2-2017005

FERREIRA, Rosa Aurea; ALVES, Alcione Corrêa. Diáspora e subalternidade na poesia de Lucrecia Panchano. Palimpsesto, Rio de Janeiro, v. 15, n 22, p. 85-101, 2016.

JARAMILLO, María Mercedes. Mary Grueso Romero: poesia, memoria e identidad. In: ORTIZ, Lucia (ed.). Chambacú, la historia la escribes tú: Ensayos sobre cultura afrocolombiana. Madrid Iberoamericana, 2007. p. 217-230. https://doi. org/10.31819/9783865278173-012

JARAMILLO, Maria Mercedes. Mary Grueso Romero: poesía, memoria e identidad. In: Ponencia inédita presentada en el XIV Congreso de la Asociación de Colombianistas. Denison University, agosto. 2005. p. 3-6. https://doi.org/10.31819/9783865278173-012

LAWO-SUKAM, Alain. Acercamiento al concepto de la negritud en la literatura afrocolombiana,Cincinnati Romance Review: Afro-Hispanic Subjectivities. Cincinnati, EUA, v. 1, n.30, p. 39-52, 2011.

LOZANO, Betty Ruth; PEÑARANDA, Bibiana. Memoria y reparación. ¿Y de ser mujeres negras qué? In: VERGARA-FIGUEROA, Aurora; et al. Descolonizando mundos: aportes de intelectuales negras y negros al pensamiento social colombiano. Ciudad Autónoma de Buenos Aires: CLACSO, 2017. p. 715-727.

MONTEALEGRE, Viviana. La ciudad como metáfora del olvido en la poesía de José Manuel Arango. In: CASTRILLÓN, Carlos A. (comp.). Marginalia: Encuentros con la literatura. Armenia: Universidad del Quindio, 2011. p. 215-226. https://doi.org/10.14349/ sumneg/2018.vg.n19.a7

MOTTA, Aparecida Suely da; BOTH, Laura Garbini. A mulher afrodescendente: sua história, luta e vitória. Cadernos da Escola de Direito e Relações Internacionais, Curitiba, v. 3, n. 16, p. 154-175, 2016.

OSORIO, Betty. Construcción estratégica de la alteridad negra en tres cuentos de Mary Grueso Romero. Revista de Crítica Literaria Latinoamericana, Lima-Boston, v. 41, n. 81, p. 149-161, 2015.

PALMEIRA, Francineide Santos. Vozes afrofemininas na literatura colombiana. Anais do SILIAFRO, v. 1, n. 1 , p. 249-257, 2012.

PALMEIRA, Francineide Santos. Escritoras na literatura afro-colombiana. Estudios de Literatura Colombiana, n. 32, p. 87-102, 2013.

PIGNATARI, Décio. O que é comunicação poética. Cotia: Ateliê Editorial, 2005.

PINTO, Sandra Regina Marcelino. A representatividade da mulher negra na poesia de Mary Grueso Romero: Afro-colombianidad e memória. In: DOMINGUEZ, Tereza Suárez; et al. Artes en femenino investigaciones situadas y performaces colaborativos. Barranquilla: Ediciones Universidad Simón Bolivar, 2016. p. 45-87. 
PRESCOTT, Laurence E. Evaluando el Pasado, Forjando el Futuro: Estado y Necesidades de la Literatura Afro-Colombiana. Revista Iberoamericana, Pittsburgh, v. LXV, n. 188-189, p. 553-565, jul./dez. 1999. https://doi.org/10.5195/reviberoamer.1999.6043

SANTOS, Walkyria Chagas da Silva. A mulher negra brasileira. Revista África e Africanidades, [S. l.], Ano 2, n. 5. p. 1-5, maio 2009. Disponivel em: http://www. africaeafricanidades.com.br/documentos/A_mulher_ negra_brasileira.pdf. Acesso em: 11 nov. 2017. https:// doi.org/10.11606/d.27.2017.tde-07112017-154.952

VALERO, Silvia. ¿De qué hablamos cuando hablamos de "literatura afrocolombiana"? o los riesgos de las categorizaciones. Estudios de Literatura Colombiana Colombia, v. 1, n. 32, p. 15-37, jan./jun. 2013. https:// doi.org/10.3989/arbor.2009.73.9n1068

SOUZA, Ricardo Luiz de et al. Negra palmera, poesia tambor y mar: construções identitárias e culturais na poética de Mary Grueso Romero. 2016.

VERGARA-FIGUEROA, Aurora; et al.Descolonizando mundos: aportes de intelectuales negras y negros al pensamiento social colombiano. Ciudad Autónoma de Buenos Aires: CLACSO, 2017.

WADE, Peter. Compreendendo a 'África'ea 'negritude'na Colômbia: a música e a política da cultura. Estudos afro-asiáticos, Rio de Janeiro, v. 25, n. 1 , p. 145-178, 2003. https://doi.org/10.1590/s0101$546 \times 2003000100007$

ZAMORANO, Alfredo Ocampo; ESCOBAR, Guiomar Cuesta. Negras Somos!: Antologia de 21 mujeres poetas afrocolombianas. Cali: Universidad del Valle, 2008.

\section{Endereço para correspondência}

Benedito Ubiratan de Sousa Pinheiro Júnior

Rua Augusto Corrêa, 01

Guamá, 66075-110

Belém, PA, Brasil

Adrielle Sena Branco

Rua Leonardo Negrão, 858

São Sebastião, 68440-000

Abaetetuba, PA, Brasil

Iris Andrade Torres

Rua Manoel da Silva Raposo, 2750

São Lourenço, 68440-000

Abaetetuba, PA, Brasil

\section{Benedito Ubiratan de Sousa Pinheiro Júnior}

Professor efetivo da Universidade Federal do Pará, doutorando em Letras pela mesma universidade. Integrante do grupo de pesquisa Narrares coordenado pela prof. Doutora. Tânia Sarmento-Pantoja. "Lá búsqueda": historia, memoria e literatura nos relatos de um sobreviver da ditadura argentina.

\section{Adrielle Sena Branco}

Graduada no curso de Licenciatura Plena em Letras - Habilitação em Lingua Portuguesa, pela Universidade do Estado do Pará - campus Moju. Graduanda do curso de Licenciatura Plena em Letras Habilitação em Língua Espanhola, pela Universidade Federal do Pará -campus Abaetetuba.

\section{Iris Andrade Torres}

Graduanda do curso de Licenciatura Plena em Letras - Habilitação em Língua Espanhola, pela Universidade Federal do Pará - campus Abaetetuba. 